\title{
Two new species of Lopesia Rübsaamen (Diptera, Cecidomyiidae) associated with Mimosa hostilis (Mimosaceae) in Brazil
}

\author{
Valéria Cid Maia ${ }^{1}$, G. Wilson Fernandes ${ }^{2}$, Henrique Magalhães ${ }^{2} \&$ Jean Carlos Santos $^{3}$
}

\begin{abstract}
'Departamento de Entomologia, Museu Nacional, Quinta da Boa Vista, São Cristóvão, 20940-040 Rio de Janeiro-RJ, Brazil. maiavcid@acd.ufrj.br ${ }^{2}$ Ecologia Evolutiva \& Biodiversidade, Universidade Federal de Minas Gerais, Caixa Postal 486, 30161970 Belo Horizonte-MG, Brazil.

${ }^{3}$ Present address: Departamento de Botânica, Centro de Ciências Biológicas, Universidade Federal de Pernambuco, Av. Prof. Moraes Rêgo s/no ${ }^{\circ}$ 50670-901 Recife-PE, Brazil.
\end{abstract}

\begin{abstract}
Two new species of Lopesia Rübsaamen (Diptera, Cecidomyiidae) associated with Mimosa hostilis (Mimosaceae) in Brazil Two new species of Lopesia Rübsaamen (Diptera, Cecidomyiidae, Lopesiini), L. mimosae Maia, sp. nov. and $L$. pernambucensis Maia, sp. nov., that induce galls on Mimosa hostilis Benth. (Mimosaceae) are described and illustrated based on material from "caatinga" in Pernambuco, Brazil.
\end{abstract}

KEYWORDS. Caatinga; Cecidomyiidae; Diptera; Lopesia; Mimosaceae.

RESUMO. Duas espécies novas de Lopesia Rübsaamen (Diptera, Cecidomyiidae) associadas a Mimosa hostilis (Mimosaceae) no Brasil. Duas novas espécies de Lopesia Rübsaamen, 1908 (Diptera, Cecidomyiidae, Lopesiini), L. mimosae Maia, sp. nov. and $L$. pernambucensis Maia, sp. nov., que induzem galhas em Mimosa hostilis Benth. (Mimosaceae) são descritas e ilustradas com base em material da caatinga de Pernambuco, Brasil.

PALAVRAS-CHAVE. Caatinga; Cecidomyiidae; Diptera; Lopesia; Mimosaceae.

One of the poorest known faunas of galling insects of Brazil is that found in the caatinga, a seasonally dry tropical forest in the northeast. The caatinga has $800,000 \mathrm{~km}^{2}\left(2^{\circ} 54\right.$ ' to $17^{\circ} 21^{\prime} \mathrm{S}$ ) representing approximately $11 \%$ of the Brazilian territory (IBGE 1985; Rizzini 1997; Leal et al. 2003). The climate is semi-arid, hot, with irregular and low precipitation. Seven to 10 months of the year are dry (RADAMBRASIL 1983; Nimer 1977).

In an attempt to start to bridge the gap in the knowledge of the galling fauna of the caating $a$ and to better understand the distribution and host plant relationships in this arid region, we describe two new species of galling insects from Mimosa hostilis Benth. (Mimosaceae). Mimosa hostilis (Mimosaceae) is a small tree that occurs widely in this seasonally dry forest. It is found in the states of Piauí, Ceará, Rio Grande do Norte, Paraíba, Pernambuco, Alagoas, Sergipe and Bahia (Oliveira et al. 1999). Mimosa hostilis is popularly known as "jurema preta" and may reach a height of 5-7 meters. Leaves are compound, alternate and bipinate with deciduous diminutive leaflets (Tigre 1976). The tree flowers during the dry season (winter, August through November). It is a spontaneous species that grows in nutrient poor soils (acid soils - $\mathrm{pH} 4.5$ ) with high aluminium content and low contents of $\mathrm{P}, \mathrm{K}, \mathrm{Ca}$, and Mg (Pereira 1998). The species is widely used in the diet of domestic animals and so is of major importance to the inhabitants of the harsh semi-arid caatinga (Carvalho Filho \& Salviano1982).

Two kinds of galls are induced on the leaflet lamina and/ or on the secondary and primary veins. They are green and each composed of two valves. One kind is bare (Fig. 1), while the other one is covered by short hairs (Fig. 2). Gall size (glabrous): $0.52 \pm 0.04 \mathrm{~cm}(\bar{X} \pm \mathrm{EP}, \mathrm{n}=50)$, hairy $(0.47 \pm$ $0,02 \mathrm{~cm}(\bar{X} \pm \mathrm{EP}, \mathrm{n}=50)$.

Both galling species belong to Lopesia Rübsaamen, 1908 (Diptera, Cecidomyiidae, Lopesiini). This genus has indistinct limits that comprises species that have four-segmented palpi; male antennae with binodal or gynecoid flagellomeres, and three separate circumfila or interconnected circumfila (as in female); $\mathrm{R}_{5}$ joining $\mathrm{C}$ beyond the wing apex; Rs closer to the end of $\mathrm{R}_{1}$ than to the arculus; tarsal claws bowed near the basal third, generally toothed (simple only in L. licaniae Gagné, 1996 in Gagné \& Hibbard, 1996); ovipositor short, barely protrusible and female cerci separate. Lopesia is known from 13 species: 3 Afrotropical, 1 Nearctic and 9 Neotropical (Gagné 2004). In this paper two new Neotropical species are described and illustrated.

\section{MATERIAL AND METHODS}

The study was done in a caatinga fragment highly impacted by human activities in the district of Parnamirim, in western Pernambuco, distant $560 \mathrm{~km}$ from the capital Recife. The climate is dry tropical, with an average temperature of 24 to $26^{\circ} \mathrm{C}$ (Andrade-Lima 1982) and an average annual precipitation of $509 \mathrm{~mm}$, at 400 m.a.s.1. $\left(39^{\circ} 57^{\prime} 00^{\prime \prime W}\right.$ 879’00”S) (Silva et al. 2000). In April 2008, 30 individuals of M. hostilis were haphazardly found in the studied area, from which 10 shoots were randomly selected around the canopy of each individual. Two distinct gall morphotypes were found on M. hostilis. Part of the samples was stored in 
plastic bags until the emergence of the galling adults and/or parasitoids. From the other part of the sample we recorded gall size and then dissected them to rear the juvenile stages of the gall inducers. Insects that merged from the galls and those obtained from dissected galls were stored in alcool $70 \%$.

The gall midges were prepared and mounted on slides following the methods of Gagné (1994). All material, including the types, was incorporated in the Diptera collection of Museu Nacional, Rio de Janeiro (MNRJ). Morphological terminology follows Gagné (1994). The field and laboratory work were done by G. W. Fernandes, C. H. P. Magalhães and J.C. Santos while the taxonomy and descriptions of the new taxa were made by V. C. Maia.

\section{Lopesia mimosae Maia, sp. nov.}

(Figs. 3-19)

Adult. Body length: 3.95-4.05 $\mathrm{mm}$ in male $(\mathrm{n}=4) ; 3.70$ $5.0 \mathrm{~mm}$ in female $(\mathrm{n}=4)$.

Head (Fig. 3). Eye facets circular; antennae with scape obconic, pedicel globose, male flagellomeres binodal and tricircumfilar, circumfila with short loops similar in length (Fig. 4); female flagellomeres cylindrical, with 2 ring-like circumfila (Fig. 5); flagellomere necks bare in both sexes; $12^{\text {th }}$ flagellomere with apical process in both sexes; flagellomeres 1 and 2 not connate. Frontoclypeus with 4-6 setae. Labrum long-attenuate with three pairs of ventral setae. Hypopharynx of same shape as labrum, with long, anteriorly directed lateral setulae. Labella elongate-convex, each with several lateral setae and 2 pairs of short mesal setae. Palpus with three setose segments, first segment globose and shortest, second and third of similar length (Fig. 6).

Thorax. Anepimeron setose, other pleural sclerites asetose. Wing (Fig. 7) length: $2.90-3.90 \mathrm{~mm}$ in male $(\mathrm{n}=4)$; 3.0-3.7 $\mathrm{mm}$ in female $(n=4) ; R_{5}$ reaching the costal margin after wing apex, Rs reaching $\mathrm{R}_{1}$ after midlength; $\mathrm{M}_{3}$ present, $\mathrm{CuA}$ forked, $\mathrm{CuP}$ present. Tarsal claws simple, empodia rudimentary (Figs. 8, 9).

Male abdomen (Figs. 10, 11). Tergites 1-7 rectangular, with complete row of caudal setae, some lateral setae, 2 basal trichoid sensilla, and elsewhere with scattered scales. Tergite 8 not sclerotized, without setae or scales, except for 2 basal trichoid sensilla. Sternites 2-7 rectangular, with setae more abundant mesally, complete row of caudal setae, some lateral setae, and 2 basal trichoid sensilla. Sternite 8 ovoid with a mesal indentation at distal margin. Male terminalia (Fig. 12). Gonocoxite extended laterally; gonostylus elongate, narrowest at midlength, setulose only basally and with ridges elsewhere, cerci convex apically, hypoproct deeply bilobed, aedeagus elongate, tapering towards apex, longer than hypoproct.

Female abdomen (Figs. 13, 14). Tergites $1-8$ as in male. Sternites 2-7 trapezoid, with setae more abundant mesally, complete row of caudal setae, some lateral setae, and 2 basal trichoid sensilla. Sternite 8 not sclerotized. Ovipositor barely protrusible; cerci elongate, triangular, separate, and setose (Fig. 15).

Pupa. Color: brownish. Body length: $3.60-4.50 \mathrm{~mm}(\mathrm{n}=5)$. Head (Fig. 16): integument grainy; antennal base thickened marginally; cephalic seta short, $0.030-0.035 \mathrm{~mm}$ in length $(n=4)$; two pairs of lower facial papillae, one pair setose and the other asetose, and three pairs of lateral papillae, one pair setose and the others asetose; upper cephalic margin thickened laterally. Thorax: prothoracic spiracle short, $0.055-$ $0.070 \mathrm{~mm}$ in length $(\mathrm{n}=5)$. Abdomen: spiracles $0.030-0.040$ $\mathrm{mm}$ in length $(\mathrm{n}=6)$, segments $3-8$ with a single row of dorsal spines at basal third and 4 dorsal papillae (Fig. 17).

Larva. Body elongate, cylindrical, tapered at both ends, thinnest anteriorly. Length: $3.70 \mathrm{~mm}(\mathrm{n}=1)$. Integument rough. Spatula $0.35 \mathrm{~mm}$ in length $(\mathrm{n}=1)$, with two welldeveloped apical teeth and elongate stalk. Lateral papillae in
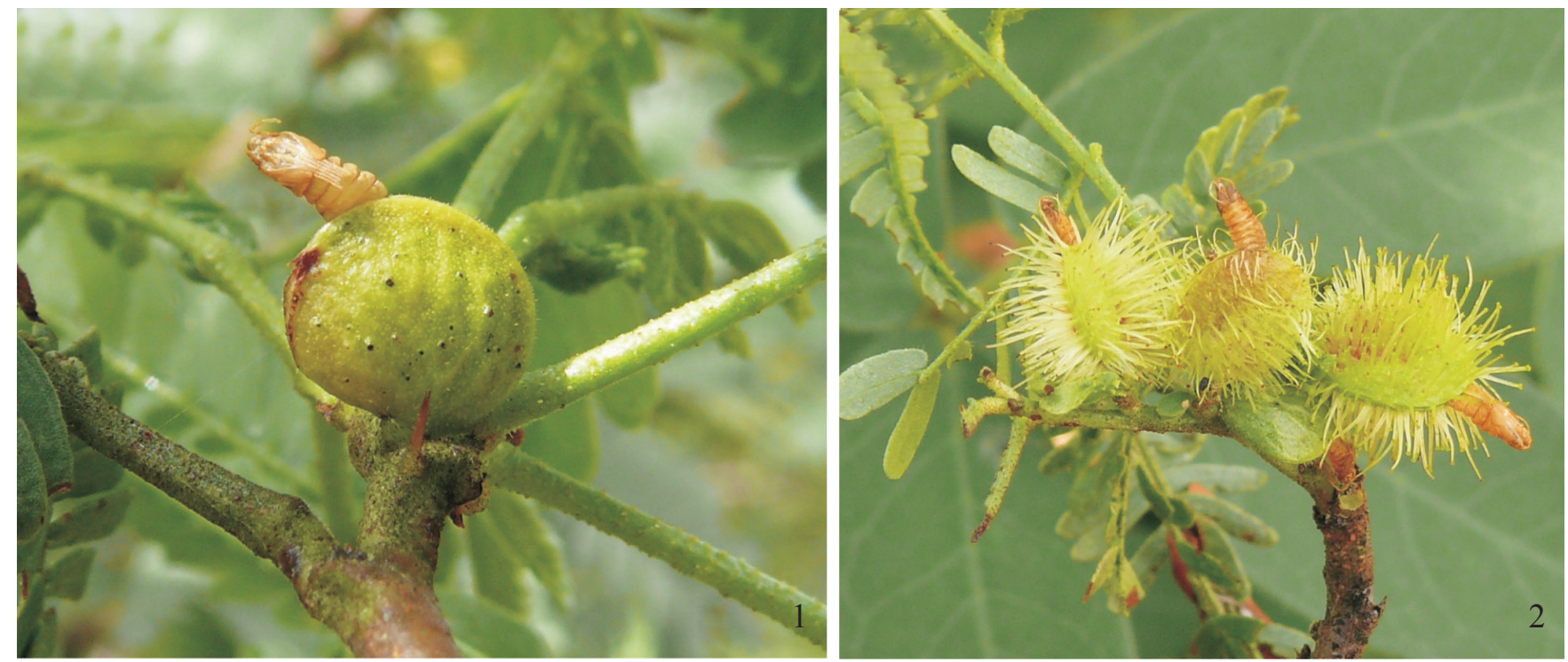

Figs. 1-2. Galls on Mimosa hostilis Benth. (Mimosaceae): 1, glabrous gall induced by L. mimosae Maia, sp. nov.; 2, hairy gall induced by $L$. pernambucensis Maia, sp. nov. 

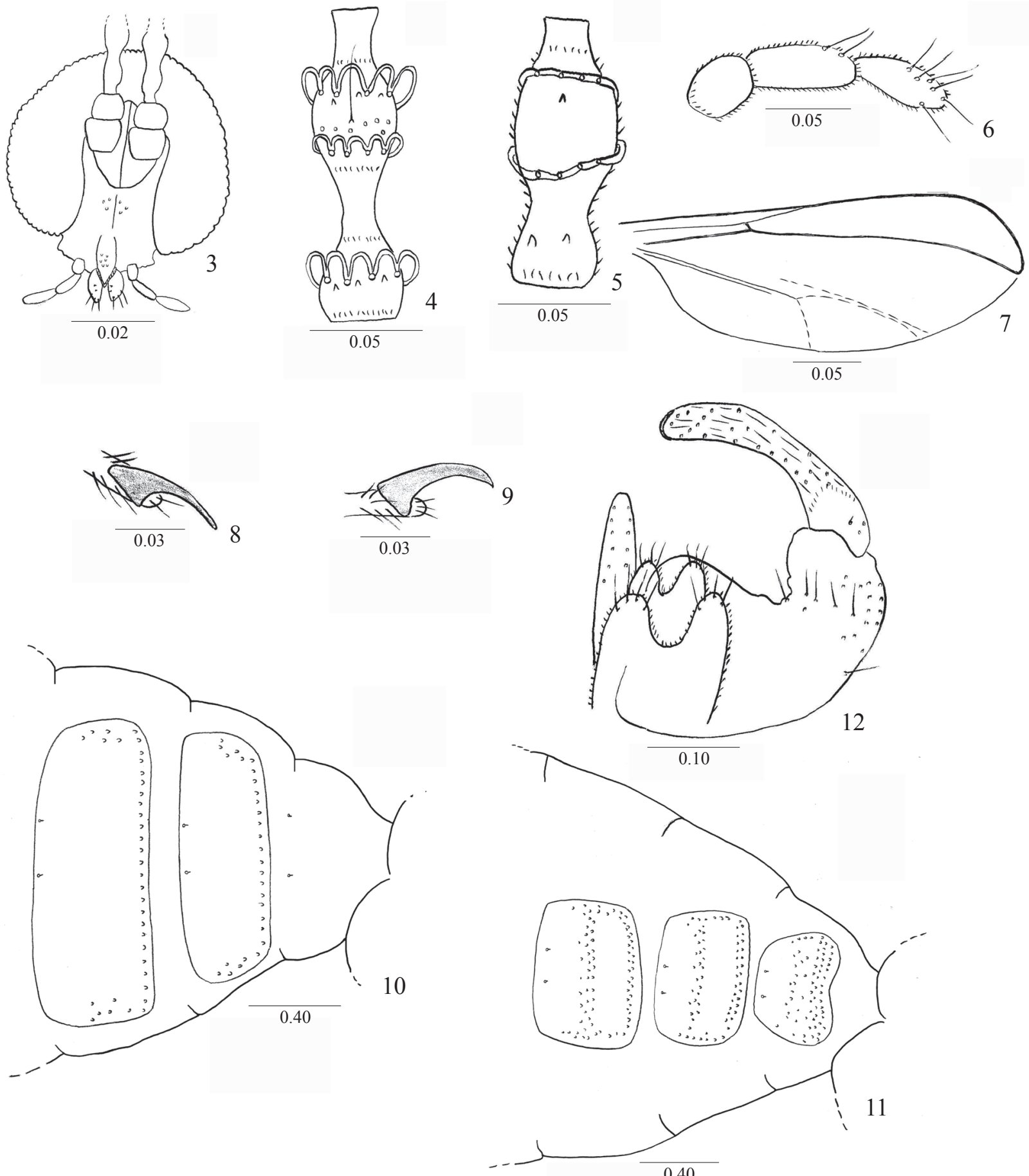

Figs. 3-12. Lopesia mimosae Maia, sp. nov.: 3, male head, frontal view; 4, male flagellomere 3; 5, female flagellomere 5; 6, male palpus; 7, male wing; 8, male tarsal claw and empodium of foreleg; 9 , female tarsal claw and empodium of midleg; 10 , male abdominal segments $6-8$, dorsal view; 11 , male abdominal segments 6-8, ventral view; 12, male terminalia, dorsal view. Scales in mm.

2 groups of three per side, 2 of each group setose, 1 asetose (Fig. 18). Terminal segment convex, with 4 pairs of corniform terminal papillae (Fig. 19).

Type material. Holotype male, BRAZIL, Pernambuco, Parnamirim, 23.IV.2008, G. W. Fernandes leg. (MNRJ). Paratypes: same data as holotype, 3 males, 4 females; 2 pupae, 7 pupal exuviae, 01 larva (MNRJ). Obtained from bivalvate, glabrous galls on Mimosa hostilis Benth.(Mimosaceae).
Etymology. The name mimosae is the genitive of the host plant generic name.

\section{Lopesia pernambucensis Maia, sp. nov.}

(Figs. 20-31)

Adult. Body length: 4.05-4.10 mm in male $(\mathrm{n}=2)$; 5.35 $5.50 \mathrm{~mm}$ in female $(\mathrm{n}=3)$. 

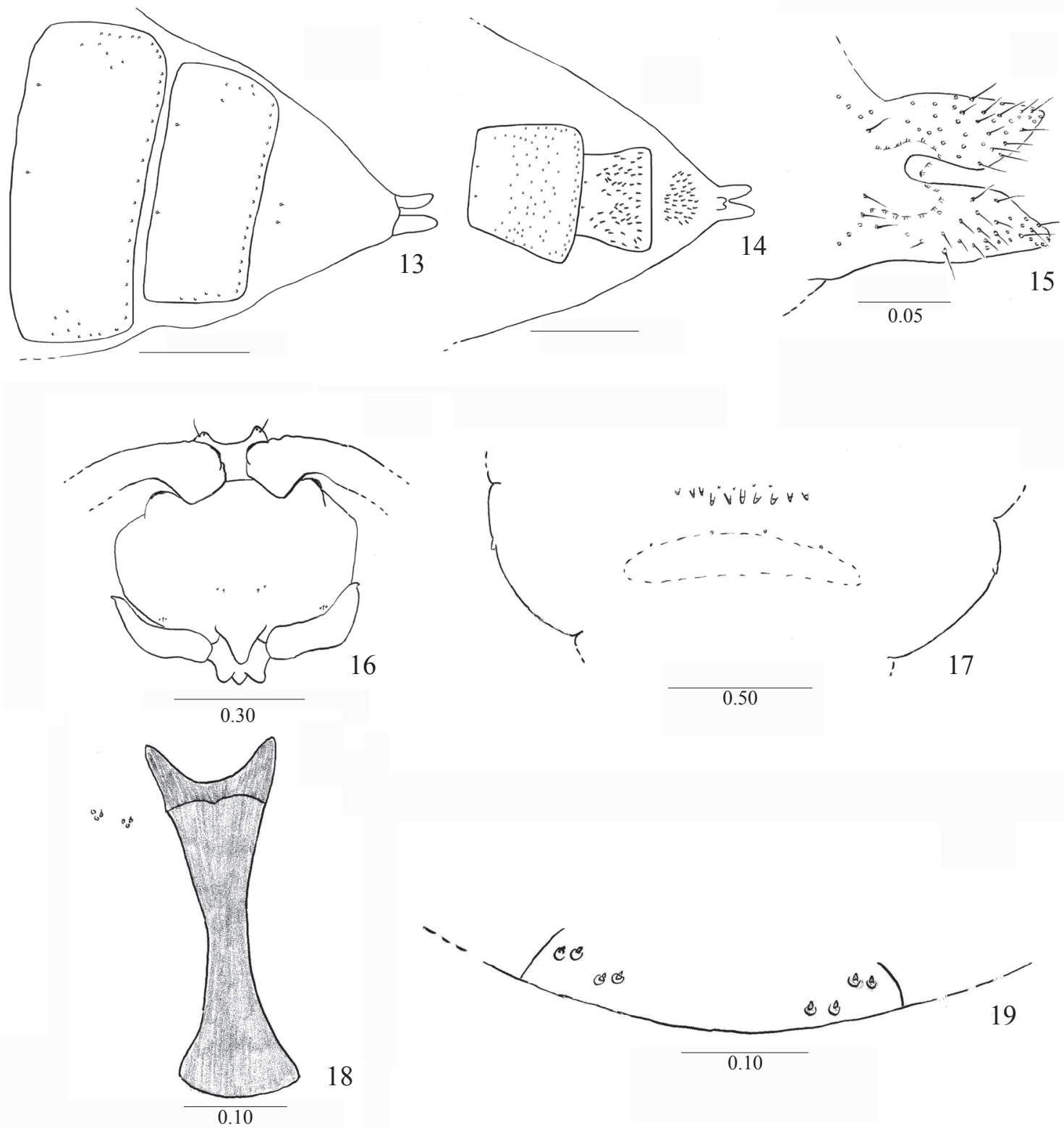

18

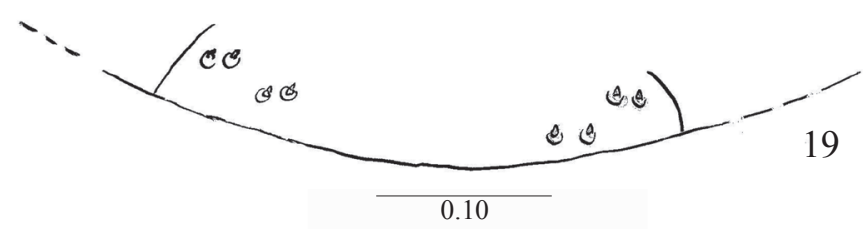

Figs. 13-19. Lopesia mimosae Maia, sp. nov.: 13, female abdominal segment 6 to end, dorsal view; 14, female abdominal segment 6 to end, ventral view; 15 , female cerci, dorsal view; 16, pupa head, ventral view; 17, pupa abdominal segment 7, dorsal view; 18, larva prothoracic spatula and lateral papillae, ventral view; 19, larva terminal segment, dorsal view . Scales in mm.

Head (Fig. 20). Antennae with scape obconic pedicel globose, male flagellomeres binodal and tricircumfilar, circumfila with short loops similar in length (Fig. 21); flagellomere necks bare; $12^{\text {th }}$ flagellomere with apical process; flagellomeres 1 and 2 not connate. Female antennae broken. Frontoclypeus with 6 setae. Labrum long-attenuate with three pairs of ventral setae. Hypopharynx of same shape as labrum, with long, anteriorly directed lateral setulae, labella elongateconvex, each with several lateral setae and 2 pairs of short mesal setae. Palpus with three setose, cylindrical segments, first segment the shortest, second and third of similar length (Fig. 22).

Thorax. Anepimeron setose, other pleural sclerites asetose. Wing (Fig. 23) length: $3.35 \mathrm{~mm}$ in male $(\mathrm{n}=1) ; 4.20 \mathrm{~mm}$ in female $(n=3) ; R_{5}$ reaching $C$ after wing apex, Rs reaching $\mathrm{R}_{1}$ after midlength, $\mathrm{M}_{3}$ present, $\mathrm{CuA}$ forked, and CuP present. Tarsal claws simple, empodium rudimentary (Figs. 24, 25).

Male abdomen (Fig. 26). Tergites 1-7 rectangular, with complete row of caudal setae, some lateral setae, 2 basal trichoid sensilla, and elsewhere with scattered scales. Tergite 8 short band-like, without setae or scales, with 2 basal trichoid sensilla. Sternites 2-7 rectangular, narrow, with setae more abundant mesally, complete row of caudal setae, some lateral setae, and 2 basal trichoid sensilla. Sternite 8 not sclerotized. Male terminalia (Fig. 27). Gonocoxite wide; gonostylus narrowest at midlength, setulose only basally, with ridges elsewhere, cerci convex apically, hypoproct deeply bilobed; aedeagus longer than hypoproct, elongate, tapering to apex. 

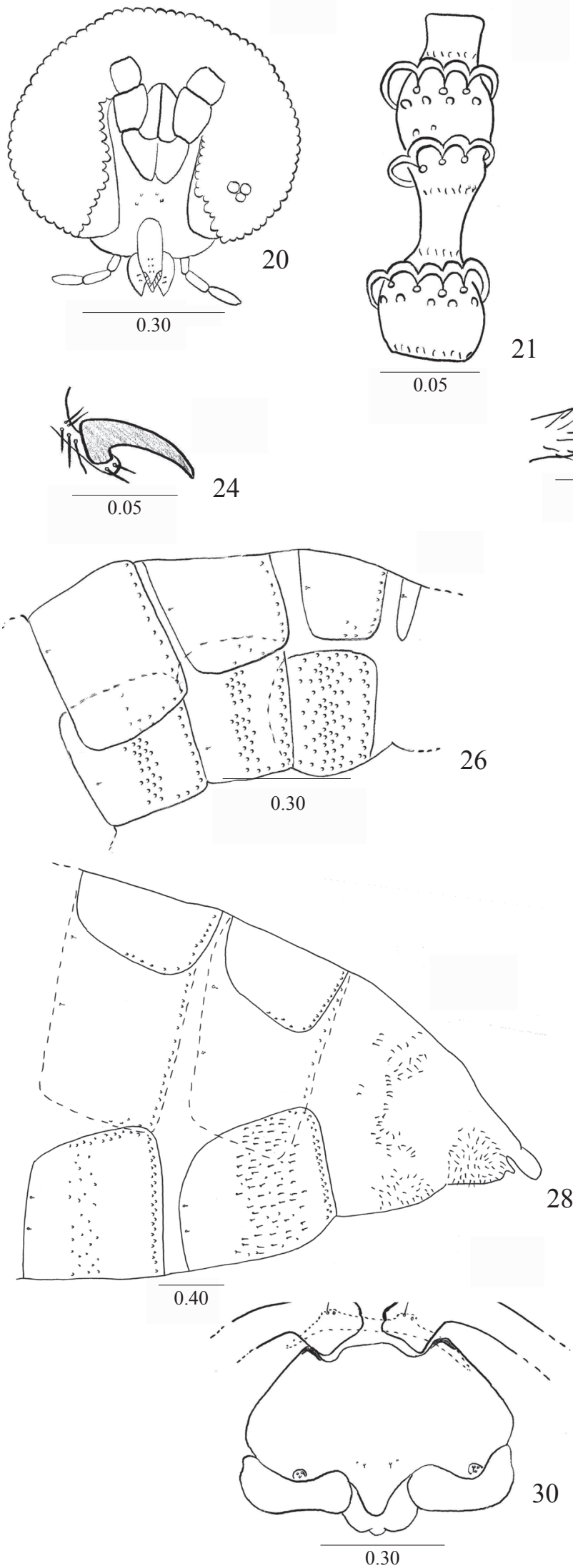

26
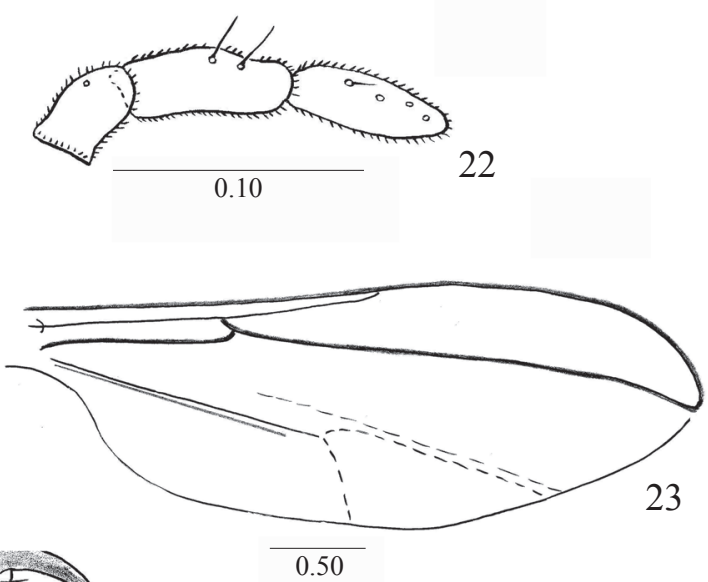

25
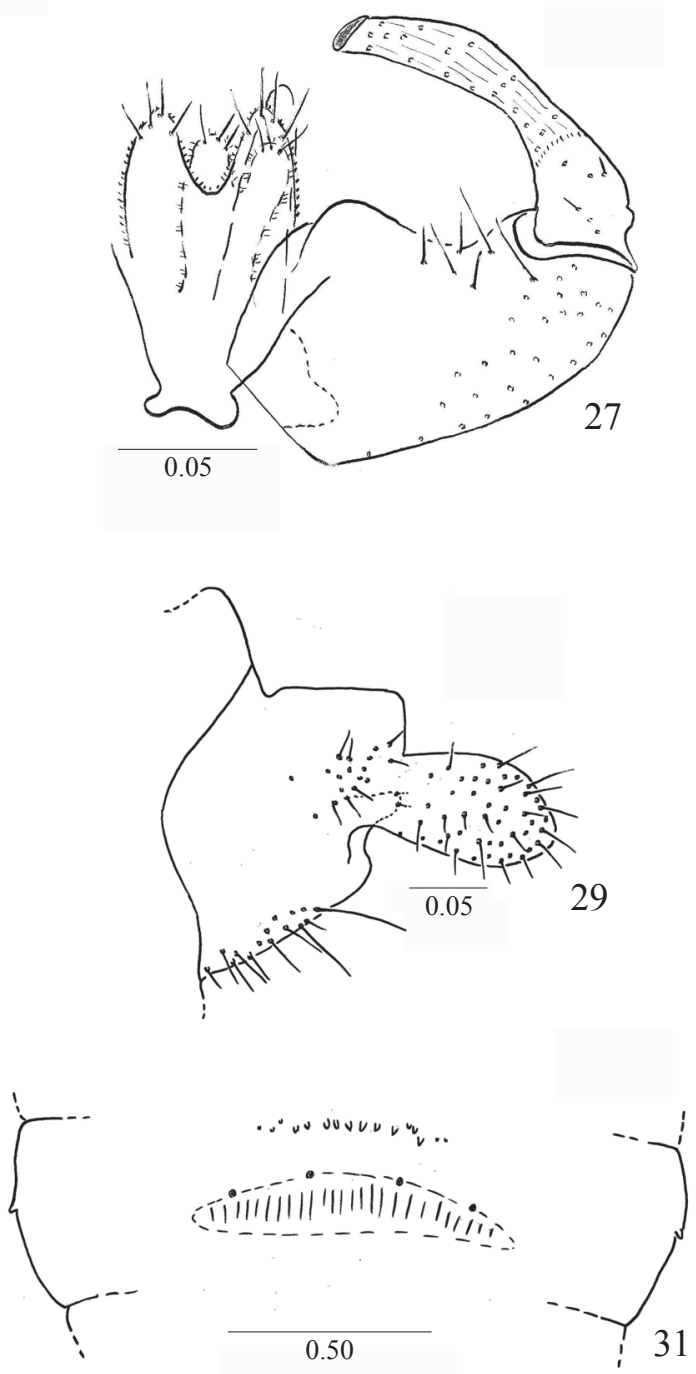

Figs. 20-31. Lopesia pernambucensis Maia, sp. nov.: 20, male head, frontal view; 21, male flagellomere 2; 22, male palpus; 23, male wing; 24, male tarsal claw and empodium of foreleg; 25 , female tarsal claw and empodium of hindleg; 26 , male abdominal segments $5-8$, lateral view; 27, male terminalia, dorsal view; 28 , female abdominal segment 6 to end, lateral view; 29, female cerci, lateral view; 30, pupa head, ventral view; 31, pupa abdominal segment 6, dorsal view. Scales in $\mathrm{mm}$. 
Female abdomen (Fig. 28): tergites 1-7 rectangular, with complete row of caudal setae, some lateral setae, 2 basal trichoid sensilla, and elsewhere with scattered scales. Tergite 8 short band-like, without setae or scales, with 2 basal trichoid sensilla. Sternites 2-7 trapezoid, with setae more abundant mesally, complete row of caudal setae, some lateral setae, and 2 basal trichoid sensilla. Sternite 8 not sclerotized. Ovipositor barely protrusible; cerci elongate-ovoid, separate, and setose (Fig. 29).

Pupa. Color: brownish. Body length: 4.40-5.15 mm $(n=5)$. Head (Fig. 30): antennal base thickened marginally; cephalic seta $0.030-0.040 \mathrm{~mm}$ in length $(\mathrm{n}=5)$; two pairs of lower facial papillae, one setose and other asetose; three pairs of lateral facial papillae, one pair setose, the others asetose; upper cephalic margin thickened laterally. Thorax: prothoracic spiracle short, with only $0.06-0.07 \mathrm{~mm}$ in length $(\mathrm{n}=5)$. Abdomen: spiracles $0.02-0.03 \mathrm{~mm}$ in length $(\mathrm{n}=5)$, segments 3-8 with a single row of dorsal spines at basal third and 4 dorsal papillae (Fig. 31).

Larva. Unknown.

Type material. Holotype male, BRAZIL, Pernambuco, Parnamirim, 23.IV.2008, G.W. Fernandes leg. (MNRJ). Paratypes: same data as holotype, 1 male, 3 females, 4 pupae, 18 pupal exuviae (MNRJ). Obtained from bivalvate, hairy galls.

Etymology. The name pernambucensis refers to the typelocality.

\section{Remarks}

Lopesia mimosae differs from $L$. pernambucensis in the length of circumfila loops (shorter in L. pernambucensis), proportions among male cercus, hypoproct and aedeagus (aedeagus noticeably longer than hypoproct and cercus in L. mimosae), and shape of female cerci (wider in $L$. pernambucensis).

Lopesia mimosae and L. pernambucensis differ from most congeners species by the simple tarsal claws. The only other species of Lopesia which has simple tarsal claws is $L$. licaniae, but that species has four palpal segments while these two new species have only three segments. Furthermore, the flagellomere necks are setulose in L. licaniae and bare in the new species and the dorsal spines on 2-8 abdominal segments of the pupa are conspicuously shortest in the new species.
Acknowledgments. We thank Dr. Raymond J. Gagné (Systematic Entomology Laboratory, USA) for his review of an earlier version of the manuscript. This study was supported by $\mathrm{CNPq}$ (Conselho Nacional de Desenvolvimento Científico e Tecnológico, Proc. 47.2084/2007-0, 30.1197/2007-05, 30.9633/2007-9), Capes/Procad 0166, and DCR-FACEPE/ CNPq (DCR-0087-2.05/06).

\section{REFERENCES}

Andrade Lima, D. 1982. Present-dry Forest refuges in northeastern Brazil, p. 254-251. In: G.T. Prance (ed.) Biological diversification in the tropics. New York, Columbia University Press, 714 p.

Carvalho Filho, O. M. \& L. M. C. Salviano. 1982. Evidências de ação inibidora da Jurema Preta na fermentação "IN VITRO" de gramíneas forrageiras. Petrolina, EMBRAPA-CPATSA, 15 p. (Boletim de pesquisa, II).

Gagné, R. J. 1994. The gall midges of the Neotropical region. Ithaca, Cornell University Press, 352 p.

Gagné, R. J. 2004. A catalog of the Cecidomyiidae (Diptera) of the world. Memoirs of the Entomological Society of Washington 25: 408 p.

Gagné, R. J. \& K. L. Hibbard.1996. A new species of gall midge (Diptera, Cecidomyiidae) from subterranean stem galls of Licania michauxii (Chrysobalanaceae) in Florida. Florida Entomologist 79: 428-434.

IBGE. 1985. Atlas nacional do Brasil. Região Nordeste. Rio de Janeiro, Fundação Instituto Brasileiro de Geografia e Estatística, p. W-3.

Leal, I. R.; M. Tabarelli \& J. M. C. Silva. 2003. Ecologia e Conservação da Caatinga. Recife, Ed. Universitária da UFPE, 822 p.

Nimer, E. 1977. Clima, p. 47-48. In: IBGE. Geografia do Brasil; região Nordeste, vol. 2 Rio de Janeiro, Editora IBGE, 454 p.

Oliveira, M. R.; J. M Rodrigues; O. Chiavone Filho \& J. T. N. Medeiros. 1999. Estudo das condições de cultivo da Algaroba e Jurema Preta e Determinação do Poder Calorífico: Revista de Ciência \& Tecnologia 14: 93-104.

Pereira, I. M. 1998. Avaliação qualitativa e quantitativa da forragem produzida pela jurema-preta (Mimosa hostilis, Benth.), pelo estrato herbáceo em área de reflorestamento. $37 \mathrm{f}$. (Monografia) - Centro de Saúde e Tecnologia Rural, Patos, Universidade Federal da Paraíba, 37p.

RADAMBRASIL 1983. Vegetação, p. 573-643. In: Folhas SC. 24/25. Aracajú/Recife. Levantamento de recursos vegetais 30 . Rio de Janeiro, RADAMBRASIL, 855 p.

Rizzini, C. T. 1997. Tratado de fitogeografia do Brasil. Rio de Janeiro, Âmbito cultural Edição Ltda, 747 p.

Silva, F. B. R.; J. C. P. Santos; N. C. Souza Neto; A. B. Silva; G. R. Riche; J. P. Tonneau; R. C. Correia; L. T. L Brito; F. H. B. B. Silva; L. G. M. C. Souza; C. P. Silva; A. P. Leite \& M. B. Oliveira Neto. 2000. Zoneamento agroecológico do nordeste: diagnóstico e prognóstico, Recife: Embrapa Solos/Escritório Regional de Pesquisa e Desenvolvimento do Nordeste (ERP/NE), Petrolina, Embrapa Semi-árido, 1CD-ROM. Documento n. ${ }^{\circ} 14$.

Tigre, C. B. 1976. Estudos de silvicultura especializada do Nordeste. Congresso Brasileiro de Florestas Tropicais II. v. XLI, Mossoró, Coleção Mossoroense, 176 p. 